\title{
Environmental conditions, air pollutants, and airway cells in runners: A longitudinal field study
}

\author{
LAURA CHIMENTI ${ }^{1}$, GIUSEPPE MORICI ${ }^{2}$, ALESSANDRA PATERNÒ ${ }^{1}$, \\ ANNA BONANNO ${ }^{3}$, MARCELLO VULTAGGIO $^{4}$, VINCENZO BELLIA ${ }^{1}, \&$ \\ MARIA R. BONSIGNORE ${ }^{1}$
}

${ }^{1}$ Department of Medicine, Pneumology, Physiology and Nutrition (DIMPEFINU) and ${ }^{2}$ Department of Experimental Medicine (DIMES), University of Palermo, ${ }^{3}$ Institute of Biomedicine and Molecular Immunology (IBIM), National Research Council, and ${ }^{4}$ Environmental Agency (AMIA), Palermo, Italy

(Accepted 3 April 2009)

\begin{abstract}
Runners have increased numbers of neutrophils in the airways at rest and after exercise compared with sedentary individuals. The aim of this study was to determine whether Mediterranean seasonal changes in temperature, humidity or airborne pollutants affect the airway cells of runners training outdoors in an urban environment. In nine male amateur runners, cell composition, apoptosis, and inflammatory mediators were measured in induced sputum collected at rest (baseline) and the morning after races held in the fall $(21 \mathrm{~km})$, winter $(12 \mathrm{~km})$, and summer $(10 \mathrm{~km})$. Concentrations of air pollutants were below the alert threshold at all times. Neutrophil differential counts tended to increase after all races $(P=0.055)$. Apoptosis of neutrophils increased with ozone $(P<0.005)$ and particulate matter $<10 \mu \mathrm{m}\left(\mathrm{PM}_{10}\right)(P<0.05)$ exposure. Bronchial epithelial cell counts were low at all times and weakly correlated with ozone and $\mathrm{PM}_{10}$ concentrations. Apoptotic bronchial epithelial cells increased after all races $(P<0.05)$. Inflammatory mediators in induced sputum were low at baseline and after the races, and correlated with neutrophil differential counts only at rest. In conclusion, apoptosis of airway cells in runners appears to be affected by both exercise and environmental conditions. Apoptosis of neutrophils increased with exposure to environmental pollutants while apoptosis of bronchial epithelial cells increased after intense exercise. Since no relationship was observed between neutrophil counts and inflammatory mediators $20 \mathrm{~h}$ after races, airways inflammation at this time point appears blunted in healthy runners and little affected by exposure to mild seasonal changes and airborne pollutants.
\end{abstract}

Keywords: Exercise, airway inflammation, ozone, $P M_{10}$, apoptosis

\section{Introduction}

There are data to indicate that habitual endurance exercise increases inflammatory cells in the airways. It has been reported that endurance athletes of winter (Karjalainen et al., 2000; Sue-Chu, Larsson, Moen, Rennard, \& Bjermer, 1999) and summer sports showed increased airway neutrophil counts (Bonsignore et al., 2001, 2003; Morici et al., 2004), both at rest and after exercise. In trained mice, we have previously reported increased inflammatory cells and damaged bronchial epithelium in small airways (Chimenti et al., 2007). However, increased inflammatory cells in the airways does not necessarily imply the occurrence of pro-inflammatory activation. Indeed, markers of inflammation in bronchoalveolar lavage fluid or induced sputum were not increased in cross-country skiers at rest (Sue-Chu et al., 2000) or in marathon runners studied at rest or after a race (Bonsignore et al., 2001). Similarly, NF- $\kappa \mathrm{B}$ nuclear translocation and $\mathrm{I} \kappa \mathrm{B} \alpha$ phosphorylation were comparable in endurance-trained and sedentary mice (Chimenti et al., 2007). Therefore, inflammatory activation in the airways of athletes appears blunted, although the mechanism involved is unclear.

Increased apoptosis may contribute to control inflammation, but data on apoptosis of inflammatory or bronchial epithelial cells in non-asthmatic human athletes are lacking. In endurance-trained mice, we previously reported increased apoptosis and proliferation of bronchiolar epithelial cells, suggesting increased epithelial turnover, while apoptosis of airway leukocytes appeared unaffected by training (Chimenti et al., 2007). 
In athletes exercising outdoors, exposure to air pollutants is an additional factor possibly affecting airway cells (D'Amato, Liccardi, D'Amato, \& Cazzola, 2002; Lebowitz, 1996; Viegi \& Enarson, 1998). People running in the city are more exposed to inhalation of particulate matter $<10 \mu \mathrm{m}\left(\mathrm{PM}_{10}\right)$ than sedentary individuals or people exercising outdoors in a rural environment (Van Wijnen, Verhoeff, Jans, \& Van Bruggen, 1995; Watt, Godden, Cherrie, \& Seaton, 1995). Ozone $\left(\mathrm{O}_{3}\right)$ exposure is at its height in the hot season and its detrimental effects on lung function may already be appreciable at concentrations much lower than the thresholds currently adopted (Brunekreef, Hoek, Breugelmans, \& Leentvaar, 1994; World Health Organization, 2005).

The aim of this study was to assess cell composition of induced sputum, apoptosis of airway cells, and the concentrations of inflammatory mediators such as interleukin 8 (IL-8) and tumour necrosis factor- $\alpha(\mathrm{TNF}-\alpha)$ in non-asthmatic runners at baseline ( 3 days before) and the day following competitive races. Environmental factors (temperature, humidity) and concentrations of the main airborne pollutants (ozone, $\mathrm{PM}_{10}$ ) were analysed to gain insight into their possible effects on airway cells and inflammatory mediators.

\section{Materials and methods}

\section{Participants and study design}

Nine amateur male runners volunteered for the study, all of whom were healthy and non-smokers. No participant used anti-inflammatory agents before or during the study period or reported a diagnosis of asthma, asthma-like symptoms or habitual use of $\beta_{2}$-agonists. No participant reported symptoms of upper respiratory tract infection (URTI) (Bermon 2007; Nieman, 1994) or upper respiratory illness (URI) (Spence et al., 2007). The study was approved by the local ethics committee, and all participants provided written informed consent.

Samples were obtained during pre-race tapering of training $(70-60 \%$ of usual training volume; "baseline") and after competitions held in November (fall, $21 \mathrm{~km}$, mean finishing time: $89.1 \pm 11.8 \mathrm{~min}$ ), February (winter, $12 \mathrm{~km}$, mean finishing time: $46.1 \pm$ $3.7 \mathrm{~min}$ ), and July (summer, $10 \mathrm{~km}$, mean finishing time: $35.4 \pm 3.5 \mathrm{~min}$ ). We did not collect samples in the spring to avoid the possible effects of increased airborne allergen concentrations. All races started at $09.00 \mathrm{~h}$ and traffic was not allowed in the circuit. Three days before and $20 \mathrm{~h}$ after the race, the participants visited the laboratory for sample collection.

Geographical context of the study. This study was conducted in Sicily, the largest island in the
Mediterranean Sea located in southern Italy. Sicily is characterized by a Mediterranean climate, with hot and dry summers intensified by the Sirocco wind and mild wet winters. Average temperatures range from $35^{\circ} \mathrm{C}$ in the summer months to $10^{\circ} \mathrm{C}$ during the winter. Precipitation is confined mainly to the winter months, most notably November, December, and January.

Air quality and environmental data collection. Data on temperature and humidity, primary $\left[\mathrm{PM}_{10}\right.$, nitrogen dioxide $\left(\mathrm{NO}_{2}\right)$ ] and secondary pollutants $\left(\mathrm{O}_{3}\right)$ were obtained from the Environmental Agency (AMIA, Azienda Municipalizzata Igiene Ambientale) in the week preceding the race and on the day of the race. The monitoring network of Palermo includes: a supervising centre for data collection, analysis, and storage; a laboratory for environmental chemical analyses; 10 monitoring points; and 89 devices for collection of chemical and physical data. Data were collected from the 10 different monitoring points in the city of Palermo where athletes habitually trained and ran competitively.

The average hourly $\mathrm{O}_{3}$ concentration from 07.00 to $15.00 \mathrm{~h}$ was taken as indicative of exposure during training and race days. Data on $\mathrm{PM}_{10}$ concentrations were recorded every $2 \mathrm{~h}$ and expressed as the average from 07.00 to $15.00 \mathrm{~h}$.

\section{Pulmonary function measurements and blood samples}

Lung function (forced expiratory volume in one second, $\mathrm{FEV}_{1} \%$ of predicted; forced vital capacity, FVC \% of predicted) was assessed by spirometry (Miller et al., 2005) in accordance with the CECA protocol (1983) (Quanjer, 1986) before and after sputum induction (Biomedin srl, Padova, Italy). A 20 -ml blood sample was drawn from the antecubital vein for preparation of plasma and serum aliquots, which were stored at $-20^{\circ} \mathrm{C}$ for subsequent analyses.

\section{Induced sputum production and processing}

Sputum induction and processing were performed according to the "plugs" method (Popov et al., 1995) with slight modifications (Koller, Nething, Otto, Urbanek, \& Eichler, 1997). After washing the oral cavity with saline, participants were exposed for $20 \mathrm{~min}$ to a hypertonic (5\%) aerosol administered with an ultrasonic nebulizer (median particle diameter $2.5 \mu \mathrm{m}$, output $1 \mathrm{ml} \cdot \min ^{-1}$; Fisoneb, Fisons Italchimici Spa, Rome, Italy). The participants coughed and expectorated into $50-\mathrm{ml}$ sterile ampoules. Samples were spread in a Petri dish and mucus plugs were selected and weighted. Phosphatebuffered saline (PBS) was added to plugs in a 4:1 weight ratio. Samples were then gently mixed and 
centrifuged (800 $\mathrm{g}$ for $20 \mathrm{~min}$ ), and supernatants were aspirated and frozen at $-20^{\circ} \mathrm{C}$ for subsequent analysis. Cell pellets were resuspended in $0.1 \%$ dithiothreitol-saline solution (DTT) in a $4: 1$ weight ratio (Sigma, St. Louis, MO), gently mixed and agitated at $25^{\circ} \mathrm{C}$ for $20 \mathrm{~min}$. The samples were then filtered (nylon filter, $70 \mu \mathrm{m}$ ) and centrifuged $(800 \mathrm{~g}$ for $10 \mathrm{~min}$ ). The supernatants were aspirated and frozen at $-20^{\circ} \mathrm{C}$. Finally, the cell pellets were resuspended in $2 \%$ human serum albumin (HSA)-saline solution, and the total cell count and viability were assessed with a standard hemocytometer and Trypan blue exclusion, respectively. Cells were then cytocentrifuged (Cytospin 2, Shandon Instruments, Runcorn, UK) and stained with Diff-Quick (MerzDade, Dudingen, Switzerland). The slides were read blind by two investigators (L.C., A.P.) who counted at least 400 cells per slide.

\section{Detection of apoptosis}

Cell pellets were resuspended in saline solution, and slides prepared and fixed with periodate-paraformaldehyde-lysine (PLP)-sucrose. Apoptosis was assessed in situ by indirect TUNEL (TdT-mediated fluorescein-dUTP Nick End Labelling, In situ Cell Death Detection kit, AP-Roche Diagnostics, Basel, Switzerland). All cytospins were lightly stained with hematoxylin and read at $40 \times$ magnification. Four hundred cells per slide were counted by two investigators (L.C., A.P.).

\section{Biochemical analysis on plasma, serum, and sputum supernatants}

Plasma total elastase and serum Clara Cell protein 16 (CC-16) concentrations were measured (Human PMN Elastase ELISA and Human Clara Cell Protein ELISA, BioVendor GmbH, Germany). Muscle enzymes [lactic dehydrogenase $(\mathrm{LDH})$ and creatine kinase $(\mathrm{CK})$ ] were determined by enzymatic assays (Olympus 640 kits and equipment, Olympus Diagnostica, Hamburg, Germany). Sputum supernatants were analysed for TNF- $\alpha$ and interleukin-8 (IL-8) (high-sensitivity and standard ELISA kits, respectively; Amersham, UK).

\section{Statistical analysis}

Data are reported as means \pm standard deviations $(s)$. Two-way analysis of variance (ANOVA) was used for data analysis with baseline and post-race conditions and time of the year as independent variables; Bonferroni correction was used for post-hoc comparisons. A non-parametric test (Spearman rank correlation) was used to assess the relationships between bronchial epithelial differential counts and concentrations of environmental pollutants. Simple linear regression was used to analyse the relationships between TNF- $\alpha$ and total cells $\left(10^{6} \cdot \mathrm{g}^{-1}\right)$ and neutrophils $\left(10^{6} \cdot \mathrm{g}^{-1}\right)$; logarithmic regression was used to analyse the relationships between IL- 8 and total cells $\left(10^{6} \cdot \mathrm{g}^{-1}\right)$ and neutrophils $\left(10^{6} \cdot \mathrm{g}^{-1}\right)$. Statistical significance was at $P<0.05$. For all tests, the same statistical package was used (StatView 5.0.1, Abacus Concept, Berkeley, CA).

\section{Results}

\section{Clinical data and pulmonary function}

The runners' mean characteristics were as follows: age $40.3 \pm 3.8$ years, body mass $70.0 \pm 7.2 \mathrm{~kg}$, and height $1.69 \pm 0.03 \mathrm{~m}$. On average, they ran $89 \pm 29 \mathrm{~km} \cdot$ week $^{-1}$ in an urban environment throughout the study period. The weekly distance covered by the runners did not change over the study period. At baseline, spirometry was normal $\left(\mathrm{FEV}_{1}\right.$ : $4.2 \pm 0.6$ litres, $112.6 \pm 13.2 \%$ of predicted; FVC: $5.1 \pm 0.5$ litres, $112.6 \pm 10.4 \%$ predicted $)$ and did not vary at any time point (data not shown). No participant reported respiratory symptoms at baseline or after races. Sputum induction did not cause symptoms or affect spirometry.

\section{Environmental conditions}

Table I reports the average environmental conditions and concentrations of main pollutants recorded during the weeks of study and on the day of the races. The greatest difference in outdoors temperature was about $18^{\circ} \mathrm{C}$ between summer and winter, the observed range reflecting the mild winter and hot summer typical of the Mediterranean climate. Air humidity was lowest in summer and highest in the fall. The highest mean values of $\mathrm{O}_{3}, \mathrm{PM}_{10}$, and $\mathrm{NO}_{2}$ were recorded in summer, but remained below the hourly limits and the alarm thresholds currently used in the European Union. Races were held on Sundays and no traffic was allowed into the circuit. However, no main difference was observed between the concentrations of pollutants recorded during the weeks of sample collection and on the day of competitions.

\section{Airway cells}

Adequate sputum samples were obtained at each time point by the athletes (fall: $n=9$ at baseline, $n=7$ post-exercise; winter: $n=9$ at baseline, $n=8$ post-exercise; summer: $n=9$ at baseline, $n=8$ post-exercise). Cell differential counts in induced sputum are shown in Figure 1. Average cell viability (Trypan blue exclusion) was $86 \pm 11 \%$, without 
Table I. Environmental conditions and pollutant concentrations recorded during the week of sample collection and on the day of the races $($ mean $\pm s)$.

\begin{tabular}{|c|c|c|c|c|}
\hline Temperature $\left({ }^{\circ} \mathrm{C}\right)$ & Humidity (\%) & $\begin{array}{l}\text { Nitrogen dioxide } \\
\left(\mathrm{NO}_{2}, \mu \mathrm{g} \cdot \mathrm{m}^{-3}\right)\end{array}$ & $\begin{array}{c}\text { Ozone } \\
\left(\mathrm{O}_{3}, \mu \mathrm{g} \cdot \mathrm{m}^{-3}\right)\end{array}$ & $\begin{array}{c}\text { Particulate matter } \\
<10 \mu \mathrm{m}\left(\mathrm{PM}_{10}, \mu \mathrm{g} \cdot \mathrm{m}^{-3}\right)\end{array}$ \\
\hline
\end{tabular}

\begin{tabular}{ccllll}
\hline Fall & & & & \\
Week & $15.6 \pm 1.6^{\star}$ & $67.0 \pm 10.7^{\star}$ & $59.5 \pm 23.2$ & $64.2 \pm 13.3^{\star}$ & $29.3 \pm 14.8$ \\
Race & $15.7 \pm 0.8$ & $60.0 \pm 2.4$ & $47.3 \pm 17.6$ & $68.9 \pm 2.9$ & $25.2 \pm 5.6$ \\
Winter & & & & \\
Week & $8.9 \pm 1.7^{\star}$ & $59.2 \pm 12.6^{\star}$ & $50.9 \pm 21.1$ & $72.6 \pm 11.4^{\star}$ & $25.2 \pm 14.5$ \\
Race & $10 \pm 0.7$ & $51.7 \pm 10.5 \#$ & $71.8 \pm 16.6 \#$ & $60.4 \pm 14.9$ & $33.0 \pm 19.9$ \\
Summer & & & & \\
Week & $27.4 \pm 1.9^{\star}$ & $51.3 \pm 11.3^{\star}$ & $63.7 \pm 22.2^{\star \star}$ & $100.4 \pm 20.6^{\star}$ & $33.9 \pm 10.8$ \\
Race & $27.5 \pm 2.1 \S$ & $64.2 \pm 5.6$ & $53.4 \pm 21.3$ & $90.3 \pm 5.7 \S$ & $31.7 \pm 13.6$
\end{tabular}

${ }^{\star} P<0.05$ for differences among all measurements (ANOVA and Bonferroni correction); ${ }^{\star \star} P<0.05$ for differences between summer and winter measurements; $\# P<0.05$ for differences between winter and fall/summer measurements; $\S P<0.0001$ for differences between summer and fall/winter measurements. Hourly limits for pollutants were: $200 \mu \mathrm{g} \cdot \mathrm{m}^{-3}$ for $\mathrm{NO}_{2}, 120 \mu \mathrm{g} \cdot \mathrm{m}^{-3}$ for ozone, and $50 \mu \mathrm{g} \cdot \mathrm{m}{ }^{-3}$ for $\mathrm{PM}_{10}$. Alarm thresholds were: $400 \mu \mathrm{g} \cdot \mathrm{m}^{-3}$ for $\mathrm{NO}_{2}$ and $240 \mu \mathrm{g} \cdot \mathrm{m}^{-3}$ for $\mathrm{O}_{3}$.
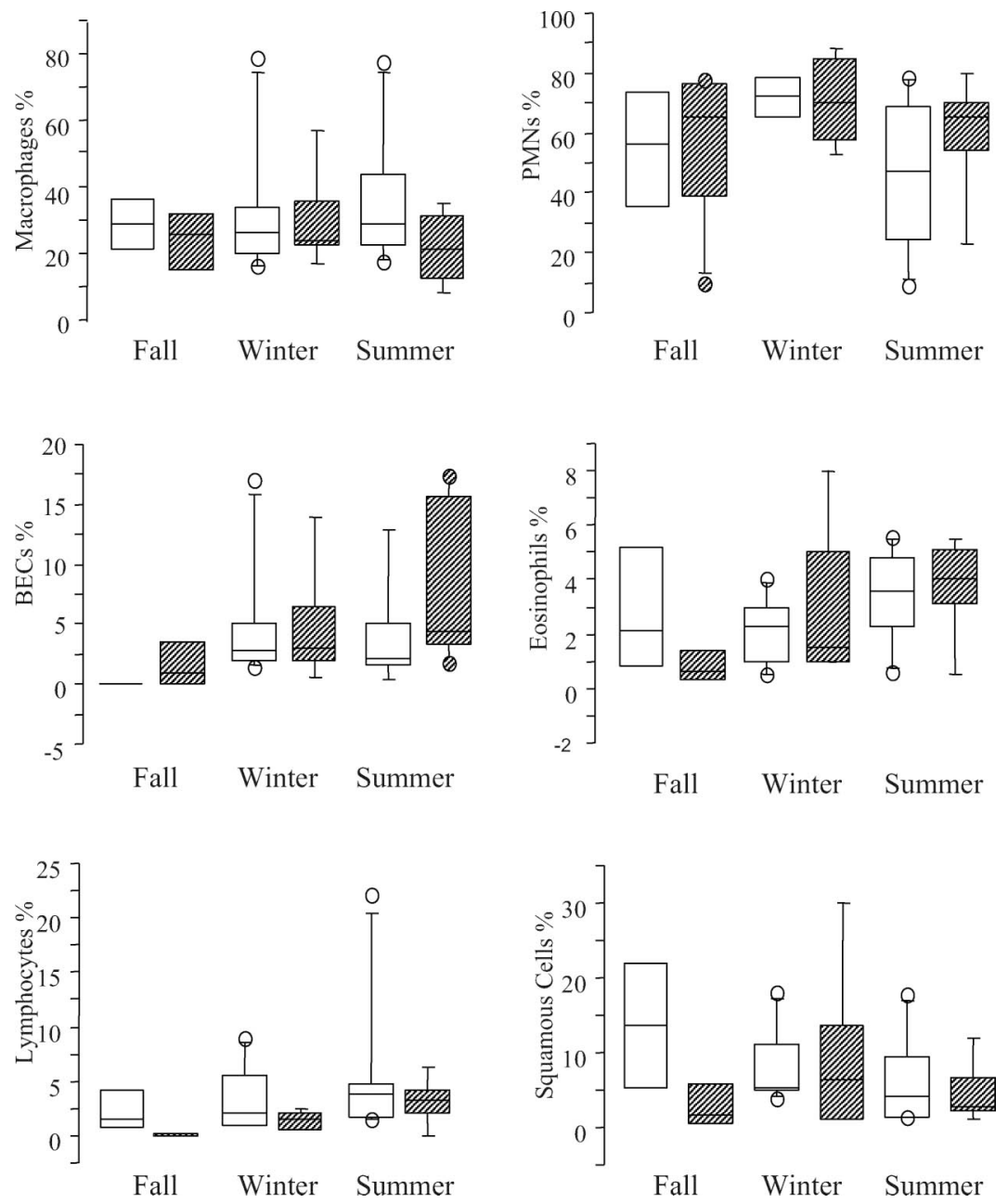

Figure 1. Differential cell counts in induced sputum at baseline (open bars) and post-race (hatched bars) at the time points of the study. $\mathrm{PMN}=$ polymorphonuclear neutrophils; $\mathrm{BEC}=$ bronchial epithelial cells. Neutrophils were the predominant cell type, and tended to increase post-race $(P=0.055)$. 
significant differences among seasons or between baseline and post-race conditions. Mean induced sputum cellularity did not show significant seasonal variations (fall total cells, baseline $1.6 \pm 2.0$. $10^{6} \cdot \mathrm{g}^{-1}$, post-race $8.4 \pm 8.7 \cdot 10^{6} \cdot \mathrm{g}^{-1}$; winter total cells, baseline $7.5 \pm 4.7 \cdot 10^{6} \cdot \mathrm{g}^{-1}$, post-race $6.9 \pm 4.9 \cdot 10^{6} \cdot \mathrm{g}^{-1}$; summer total cells, baseline $5.8 \pm 7.8 \cdot 10^{6} \cdot \mathrm{g}^{-1}$, post-race $\left.4.3 \pm 4.7\right)$. Mean neutrophil differential counts tended to increase post-race $(P=0.055)$, while bronchial epithelial cell differential counts did not show significant differences among seasons or between baseline and postrace conditions.

Weak correlations were observed between increasing $\mathrm{O}_{3}$ concentrations and bronchial epithelial cell differential counts (Spearman's $\rho=0.467, P<0.05$; Figure 2), but not neutrophil or macrophage differential counts or absolute counts of any cell type. The concentration of $\mathrm{PM}_{10}$ also showed a weak association with bronchial epithelial cell differential counts $(\rho=0.408, P<0.05)$ (Figure 2$)$ but not with neutrophils or other cell types (data not shown). No correlation was observed between temperature, air humidity or $\mathrm{NO}_{2}$ concentrations and cell counts or inflammatory mediator concentrations in induced sputum.

Apoptosis. Apoptotic cells expressed as percentages of total cells in induced sputum are reported in Figure 3 (upper panel). Apoptosis of airway cells was highest in summer samples, with no significant differences between baseline and post-race samples. Total apoptosis increased with increasing $\mathrm{O}_{3}(r=0.76$, $P<0.0005)$ and $\mathrm{PM}_{10}(r=0.61, P<0.01)$ concentrations (Figure 3, middle and lower panels).

On average, neutrophils accounted for most total apoptotic cells, with no significant differences among seasons or between baseline and post-race conditions (Figure 4A). Apoptosis of neutrophils as a percentage of total neutrophil counts was in the normal range (18-55\%; Rytila et al., 2006) in the fall and winter samples, and increased in summer $(P<0.05$ vs. other time points), without significant differences between baseline and post-race conditions (Figure 4B). Significant correlations were observed between the percentage of apoptotic/total neutrophil counts and average weekly exposure to $\mathrm{O}_{3}$ $(r=0.70, P<0.005$; Figure $4 \mathrm{C})$ and $\mathrm{PM}_{10}(r=0.56$, $P<0.05$; Figure 4D).

The contribution of bronchial epithelial cells to total apoptosis increased after all competitions, from $1.1 \pm 2.0 \%$ at baseline to $13.3 \pm 15.3 \%$ post-race $(P<0.05)$, irrespective of season (Figure $4 \mathrm{E})$. However, apoptosis of bronchial epithelial cells as a percentage of total bronchial epithelial cell counts did not vary significantly according to season or condition (Figure $4 \mathrm{~F}$ ), and did not correlate with $\mathrm{O}_{3}$ or $\mathrm{PM}_{10}$ exposure levels.

\section{Inflammatory mediators in sputum}

The concentration of TNF- $\alpha$ in sputum supernatant was low at baseline and post-race irrespective of season (Figure 5A), and correlated with total cell and neutrophil absolute counts only at baseline (Figure 5B, C). Interleukin-8 showed a similar behaviour (Figure 5D-F). No correlation was observed between the concentration of inflammatory mediators and apoptosis of airway cells (data not shown).

\section{Blood analyses}

Muscle enzymes (Table II) increased only after the longest race (fall, $21 \mathrm{~km}$ ). Plasma elastase concentration was low all times (Table II). As a marker of pulmonary damage, the Clara cell-derived protein CC-16 was measured in serum. The concentrations of CC-16 were in the normal range in all participants at rest and did not vary significantly from baseline to
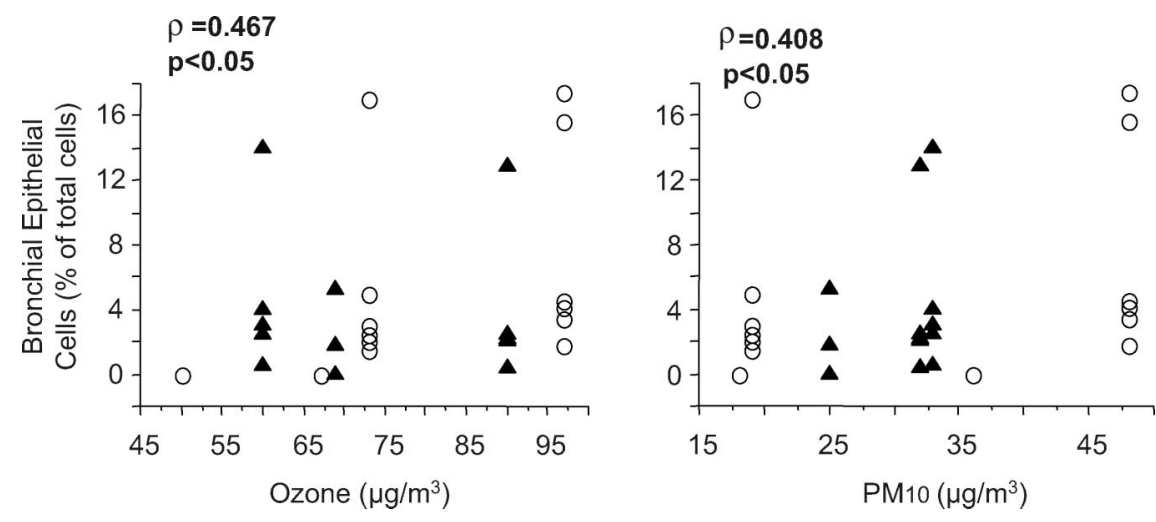

Figure 2. Correlations between bronchial epithelial cells (BEC) differential counts in induced sputum and ozone (left panels) and PM 10 (right panels) concentrations. $\bigcirc$, baseline; $\bullet$, post-race. 

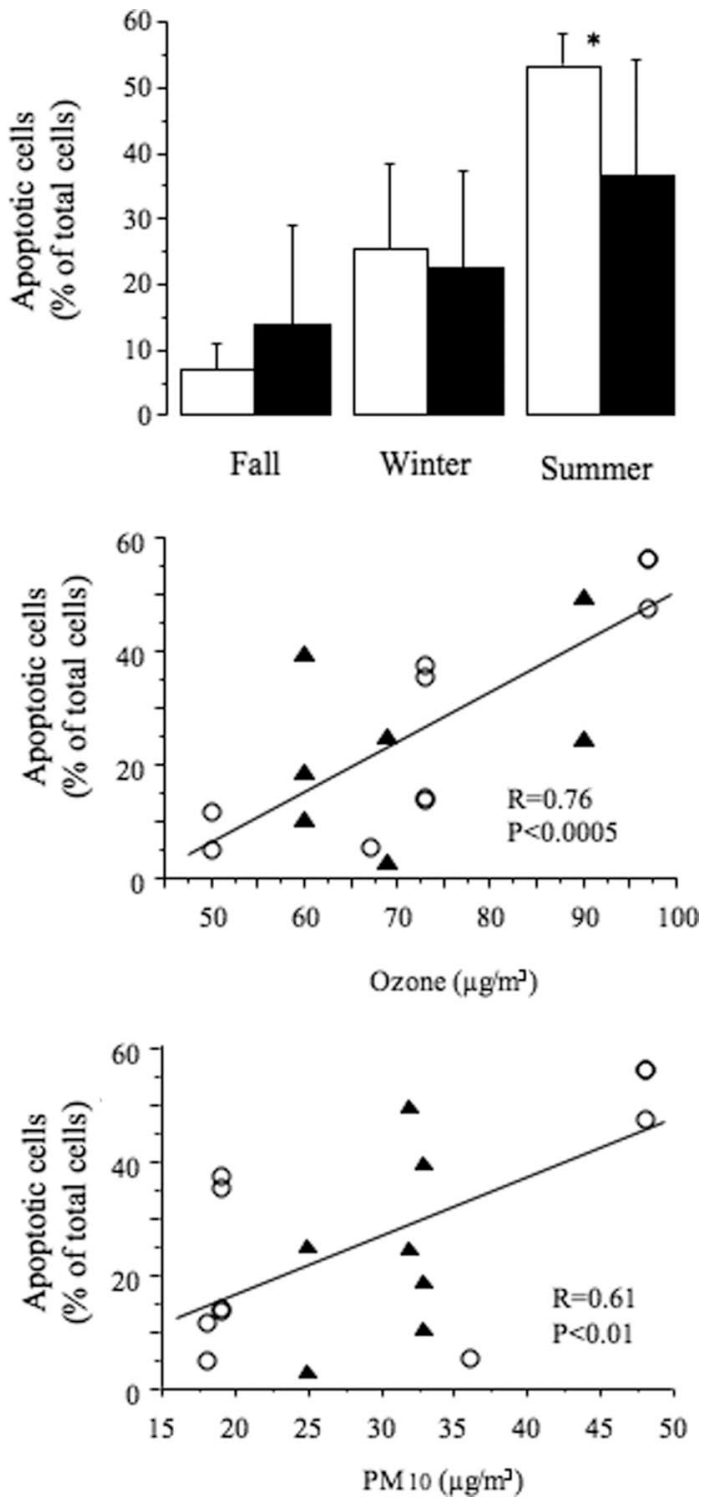

Figure 3. Total apoptosis in induced sputum. (Upper panel) Apoptosis of airway cells was highest in summer samples for both baseline and post-exercise values ( $p<0.05$ vs. fall and winter), and correlated with ozone (middle panel) and $\mathrm{PM}_{10}$ (lower panel) exposure. Empty bars and empty circles = baseline; filled bars and filled triangles $=$ post-race

post-race conditions, or among different time points (Table II).

\section{Discussion}

Air pollution is a significant variable to consider when assessing the effects of exercise on airway cells in healthy athletes. As a result of the increased ventilation during endurance exercise, runners are at special risk of inhaling air pollutants, especially when exercise is performed outdoors in competitive events (Carlisle \& Sharp, 2001). In addition, local temperature, precipitation or radiation may affect air pollutant concentrations and thus air quality (Ebi \&
McGregor, 2008). This longitudinal field study was designed to assess the possible interactions between exercise and average airborne pollutants/seasonal climate changes on airway cells in non-asthmatic amateur runners living in the Mediterranean island of Sicily. The main findings were: (a) mild bronchial epithelial injury is associated with intense exercise, irrespective of environmental conditions; (b) ozone and $\mathrm{PM}_{10}$ affect apoptosis of neutrophils, suggesting activation of anti-inflammatory mechanisms in response to inhalation of pollutants during exercise.

Before discussing the results in detail, some features of this study need comment. In contrast to our previous studies, induced sputum samples were processed by the "plug" technique (Koller et al., 1997; Popov et al., 1995), but not all participants were able to provide adequate samples on all occasions, possibly accounting for the lack of significance of some results. In addition, we did not collect induced sputum shortly after the race because in animal models influx of neutrophils started about $2 \mathrm{~h}$ after airway challenge with dry and cold air (Davis, Schoefield, \& Freed, 2003). This may explain the lack of increased neutrophil counts in rowers and swimmers after acute exercise lasting $1 \mathrm{~h}$ or less compared with a marathon race (Bonsignore et al., 2003; Morici et al., 2004). Moreover, the athletes were required to perform a protocol lasting several hours on the day of the race (always on Sunday) on repeated occasions. Induced sputum samples were, therefore, collected about $20 \mathrm{~h}$ after the race. Experiments were conducted according to races that occur during the year in Palermo, in order to use the air quality measurements collected by the city's monitoring system. Due to the lack of true "resting" conditions in people who run every day, samples collected during pre-race tapering were considered as "baseline" in our study. We could at best estimate the level of exposure to pollutants in our athletes, due to variations in pollutant concentrations at different times of the day and variable exercise-associated changes in ventilation among participants. Exposure to pollutants during races was quite low, since the races were held on Sundays and no traffic was allowed into the circuit. Therefore, we chose to consider the average level of exposure during the entire week as representative of "seasonal" exposure conditions.

In brief, neutrophils and bronchial epithelial cells showed contrasting behaviours. After intense exercise, neutrophil counts, in induced sputum, tended to increase while their apoptosis was unaffected; conversely, bronchial epithelial cell counts were similar at baseline and post-race, but their apoptosis increased in post-race samples suggesting mild epithelial damage associated with intense exercise. These data in humans are strikingly similar to 

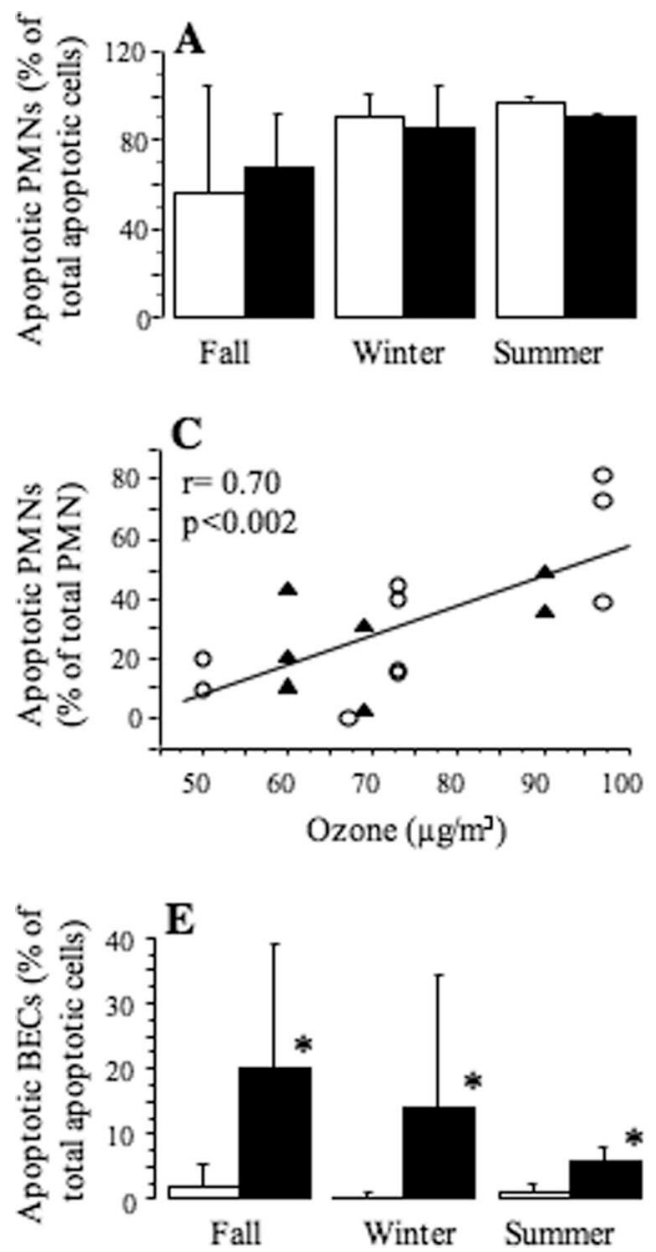
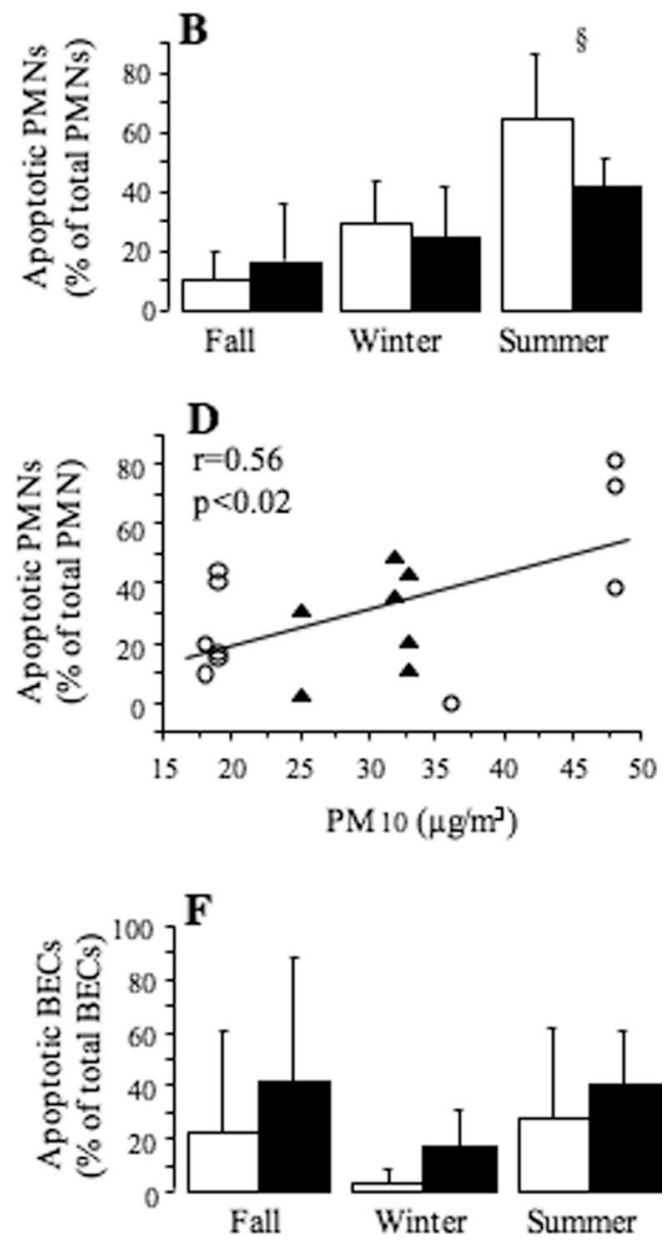

Figure 4. Apoptosis of airway polymorphonuclear neutrophils (PMN) (upper panels, A-D) and bronchial epithelial cells (BEC) (lower panels, E, F). Neutrophils accounted for the majority of apoptotic cells at all times (A), while the percentage of bronchial epithelial cells increased significantly in the post-race samples $(\mathrm{E})$. Absolute counts of apoptotic neutrophils were highest in summer $(\mathrm{B} ; \S P<0.05$ vs. other time points), while no significant difference was observed for bronchial epithelial cells (F). Apoptosis of neutrophils increased with ozone (C) and $\mathrm{PM}_{10}$ (D) exposure. Symbols as in Figure 3.

previous data obtained in endurance-trained mice, where we found increased apoptosis of bronchiolar epithelial cells, while apoptosis of airway leukocytes appeared unaffected by exercise (Chimenti et al., 2007). As for the effects of environmental conditions, airborne pollutants appeared to be associated with increased bronchial epithelial cells but not neutrophil counts; however, only apoptosis of neutrophils was found to correlate with the level of exposure to $\mathrm{O}_{3}$ and $\mathrm{PM}_{10}$.

The concentrations of inflammatory mediators and markers of cell damage did not vary with exercise or changes in average pollutant concentrations. Anti-inflammatory mechanisms may operated physiologically in the airways of well-trained individuals (Bonsignore et al., 2001, 2003; Chimenti et al., 2007; Karjalainen et al., 2000; Morici et al., 2004; Sue-Chu et al., 1999). Because apoptosis plays an important role in anti-inflammatory and anti-immunogenic responses (Haslett, 1999), we hypothesized that increased apoptosis might be involved in the lack of inflammatory activation in runners (Bonsignore et al., 2003).

In normal individuals, 34\% (range 18-55\%) of neutrophils in induced sputum have been found to be apoptotic (Rytila et al., 2006). Intense exercise did not affect apoptosis of neutrophils significantly, similar to our previous research (Chimenti et al., 2007). Total cell and neutrophil apoptosis increased in summer, when the highest concentrations of $\mathrm{O}_{3}$ and $\mathrm{PM}_{10}$ were recorded, and significant correlations were observed between apoptosis of neutrophils and exposure to pollutants. Therefore, our results do not support the hypothesis that exercise may favour neutrophil apoptosis in the airways, but suggest that airborne pollutants affect apoptosis of neutrophils.

Previous studies have reported that acute $\mathrm{O}_{3}$ exposure promotes influx of neutrophils into the airways and triggers inflammation (Holz et al., 1999). However, the acute response to ozone appeared 

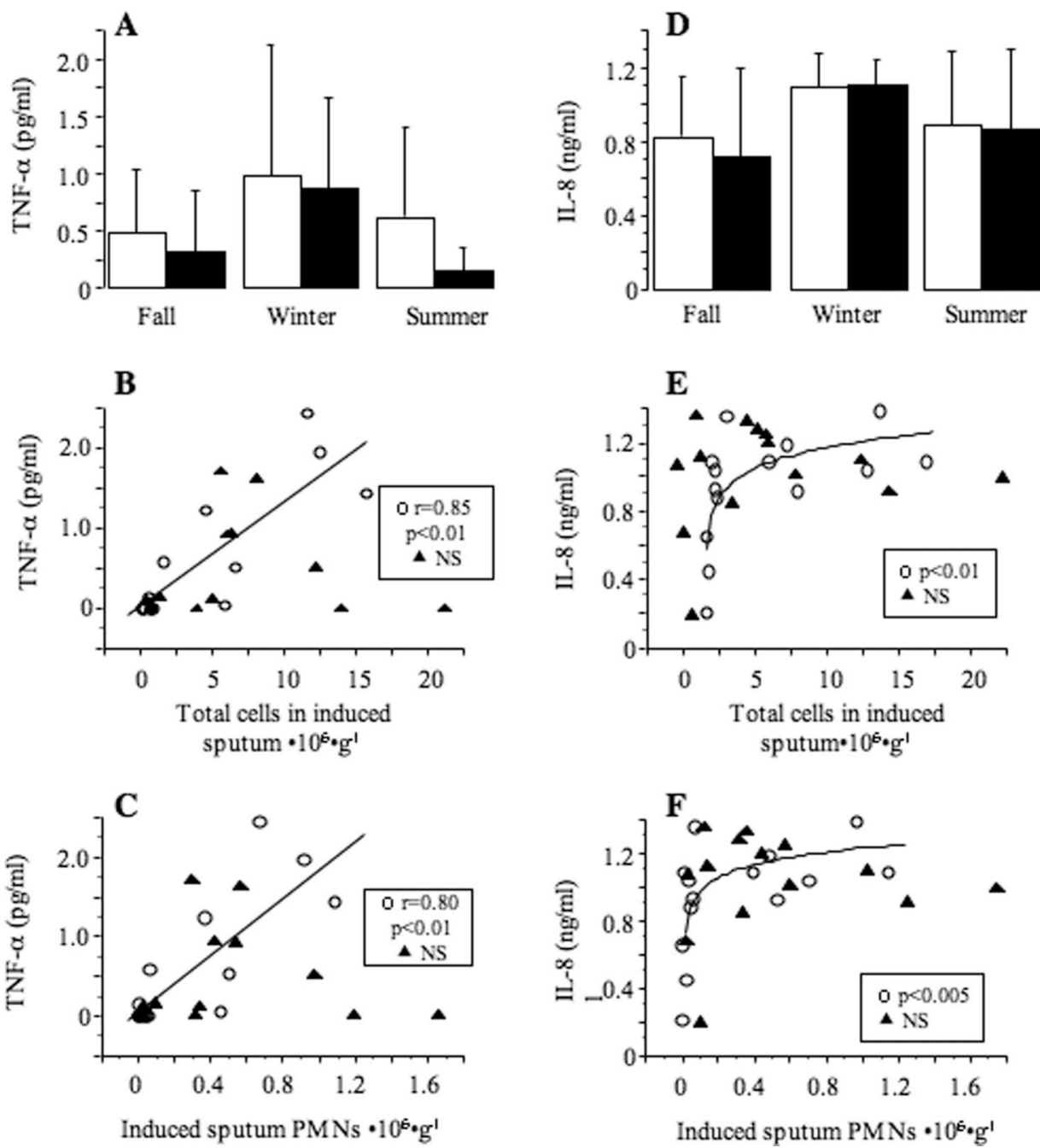

Figure 5. Inflammatory mediators in induced sputum samples. Symbols as in Figure 3. Mean concentrations of TNF- $\alpha$ (A) and IL-8 (C) did not show significant differences according to baseline or post-race conditions or to time points. Both TNF- $\alpha$ and IL- 8 showed positive correlations with total cell (B, E) and polymorphonuclear neutrophil (PMN) (C, F) counts in induced sputum only at baseline (open circles), not post-race (solid triangles).

Table II. Serum muscle enzymes, elastase, and CC-16 concentrations.

\begin{tabular}{|c|c|c|c|c|c|c|}
\hline & \multicolumn{2}{|c|}{ Fall $(21 \mathrm{~km})$} & \multicolumn{2}{|c|}{ Winter $(12 \mathrm{~km})$} & \multicolumn{2}{|c|}{ Summer $(10 \mathrm{~km})$} \\
\hline & Baseline & Race & Baseline & Race & Baseline & Race \\
\hline $\mathrm{CPK}\left(\mathrm{IU} \cdot 1^{-1}\right)$ & $277 \pm 69$ & $600 \pm 316^{\star}$ & $294 \pm 172$ & $296 \pm 123$ & $264 \pm 126$ & $203 \pm 53$ \\
\hline $\mathrm{LDH}\left(\mathrm{IU} \cdot 1^{-1}\right)$ & $452 \pm 48$ & $636 \pm 139^{\star}$ & $493 \pm 100$ & $477 \pm 87$ & $452 \pm 74$ & $476 \pm 52$ \\
\hline Elastase $\left(\mathrm{ng} \cdot \mathrm{ml}^{-1}\right)$ & $41 \pm 10$ & $79 \pm 60$ & $37 \pm 13$ & $38 \pm 6$ & $38 \pm 9$ & $36 \pm 10$ \\
\hline $\left.\mathrm{CC}-16 \mathrm{ng} \cdot \mathrm{ml}^{-1}\right)$ & $7.2 \pm 2.6$ & $7.6 \pm 2.3$ & $8.8 \pm 3.1$ & $8.8 \pm 3.2$ & $8.0 \pm 3.6$ & $8.7 \pm 4.2$ \\
\hline
\end{tabular}

${ }^{\star} P<0.05$ vs. baseline condition.

gradually to attenuate during a 3-day exposure, and was associated with increased apoptotic neutrophils in bronchoalveolar lavage in rats (Ishii et al., 1998). Similarly, lung granulocytes from calves exposed to $0.75 \mathrm{ppm}_{3}$ for 7 consecutive days showed downregulation of $\mathrm{Bcl}-\mathrm{x}(\mathrm{L})$ and $\mathrm{Bcl}-2$, two anti-apoptotic proteins, suggesting that $\mathrm{O}_{3}$ adaptation is associated with increased apoptosis (Fievez et al., 2001). Our findings are in line with these results, as a significant correlation was observed between $\mathrm{O}_{3}$ concentrations and neutrophil apoptosis, but not with differential or absolute neutrophil counts in sputum. Therefore, neutrophil apoptosis in the airways may limit airway 
inflammation under conditions of repeated $\mathrm{O}_{3}$ exposure in human athletes.

Similarly, apoptosis of induced sputum neutrophils, but not their differential or absolute counts, correlated weakly with $\mathrm{PM}_{10}$ concentrations. To our knowledge, no study has assessed the independent effect of $\mathrm{PM}_{10}$ on neutrophil apoptosis, while both pro-apoptotic and pro-inflammatory effects of $\mathrm{PM}_{10}$ have been reported in alveolar macrophages (Huang, Li, Harder, \& Soukup, 2004).

In contrast to neutrophils, bronchial epithelial cell differential counts were within the normal range, but correlated weakly with $\mathrm{O}_{3}$ and $\mathrm{PM}_{10}$ correlations. Ozone inhalation, even at concentrations below the alarm threshold, can damage airway epithelium (Jabbour, Altman, Wight, \& Luchtel, 1998) and promote the release of pro-inflammatory mediators (Rusznak, Devalia, \& Davies, 1996). Although no absolute increase in apoptosis of bronchial epithelial cells was observed in our athletes, the contribution of bronchial epithelial cells to total apoptosis was always higher after a race, independent of season. We had previously reported increased epithelial apoptosis and proliferation in bronchiolar epithelial cells in mice trained for 45 days (Chimenti et al., 2007). The present results are in line with the occurrence of mild epithelial damage during intense exercise. Bronchial epithelial cells protect the airways against external agents, not only by acting as a physical and functional barrier but also by modulating airway inflammation and repair processes (Tesfaigzi, 2006). With regard to exercise, bronchial epithelial cells may be affected by osmotic changes triggered by exercise hyperventilation (Anderson \& Kippelen, 2008; Hashimoto et al., 1999). Bronchial epithelial damage was found after exercise in horses breathing cold air (Davis, Lockard, Marlin, \& Freed, 2002), and in dogs challenged at rest with dry air insufflations into a pulmonary segment (Davis et al., 2003). In humans, bronchial epithelial cells in induced sputum tended to increase after very heavy exercise (Morici et al., 2004).

We have previously reported bronchiolar epithelial damage and repair associated with endurance training in mice (Chimenti et al., 2007). In this study, we measured CC-16 in serum at baseline and after races as a marker of distal lung epithelial damage. CC-16 is a $16-\mathrm{kDa}$ protein released by Clara cells (Hermans et al., 1999) used as a biomarker of increased lung epithelial permeability, especially in the early stage of toxic lung injury by air pollutants (Jabbour et al., 1998). An increase in CC-16 has been found shortly after exercise (Nanson, Burgess, Robin, \& Bernard, 2001) and after $\mathrm{O}_{3}$ exposure at rest (Arsalane et al., 1999) or during exercise (Broeckaert et al., 2000). In the present study, serum CC-16 was not increased in post-race samples, suggesting that we may have missed its transient early increase.

Interleukin- 8 and TNF- $\alpha$ mediate recruitment of neutrophils during airway inflammation (Kobayashi, 2008). An increase of IL-8 concentrations was observed in runners during the competitive period compared with basic endurance training but no correlations were observed with sputum cells counts (Denguezli et al., 2008). However, these results may be related to the different experimental conditions, as the samples were collected $2 \mathrm{~h}$ after a training session. The low concentrations of IL- 8 and TNF- $\alpha$ in induced sputum supernatants suggest that inflammatory activation in the airways was blunted after intense exercise. Moreover, they correlated with total cell and neutrophil counts in induced sputum only at baseline, showing no relationship with the exerciseinduced increase in airway neutrophils. Finally, IL-8 and $\mathrm{TNF}-\alpha$ did not correlate with pollutant concentrations. We speculate that habitual exercise may down-regulate inflammatory responses, including those to pollutants. A robust control of airway inflammation in trained individuals, possibly mediated by increased antioxidant defences (Bergamaschi et al., 2001), may at least partly explain the protective effects of exercise on respiratory health recently reported in a longitudinal population study (GarciaAymerich, Lange, Benet, Schnohr, \& Anto, 2007), in which regularly exercising smokers showed less decline in lung function over time than sedentary smokers.

In summary, our results suggest that both exercise and exposure to airborne pollutants affect airway cells in healthy runners. However, the narrow temperature and humidity range explored, typical of the Mediterranean climate, might be insufficient to determine major changes in airway cells. Intense exercise caused mild epithelial injury, but did not cause significant inflammatory activation $20 \mathrm{~h}$ after a race, perhaps because of the increased apoptosis of bronchial epithelial cells. Alternatively, we could have missed an earlier transient inflammatory response due to sample timing, although our previous data would not support this possibility (Bonsignore et al., 2001, 2003; Morici et al., 2004; Chimenti et al., 2007). Ozone and $\mathrm{PM}_{10}$ concentrations were associated with increased bronchial epithelial cell counts and neutrophil apoptosis in induced sputum. We conclude that: (a) epithelial injury associated with intense exercise is mild; and (b) ozone and $\mathrm{PM}_{10}$ may increase airway cell apoptosis, suggesting activation of anti-inflammatory mechanisms in response to pollutant inhalation during exercise. Although the environmental conditions were mild, our results do not suggest a major detrimental effect of either exercise or modest concentrations of air pollutants on respiratory health. 


\section{References}

Anderson, S. D., \& Kippelen, P. (2008). Airway injury as a mechanism for exercise-induced bronchoconstriction in elite athletes. Fournal of Allergy and Clinical Immunology, 122, 225-235.

Arsalane, K., Broekaert, F., Knoops, B., Clippe, A., Buchet, J. P., \& Bernard, A. (1999). Increased serum and urinary concentrations of lung Clara cell protein in rats acutely exposed to ozone. Toxicology and Applied Pharmacology, 159, 169-174.

Bergamaschi, E., De Palma, G., Mozzoni, P., Vanni, S., Vettori, M. V., Broeckaert, F., et al. (2001). Polymorphism of quinonemetabolizing enzymes and susceptibility to ozone-induced acute effects. American Fournal of Respiratory and Critical Care Medicine, 163, 1426-1431.

Bermon, S. (2007). Airway inflammation and upper respiratory tract infection in athletes: Is there a link? Exercise Immunology Review, 13, 6-14.

Bonsignore, M. R., Morici, G., Riccobono, L., Insalaco, G., Bonanno, A., Profita, M., et al. (2001). Airway inflammation in non-asthmatic amateur runners. American fournal of Physiology: Lung, Cellular and Molecular Physiology, 281, L668-L676.

Bonsignore, M. R., Morici, G., Riccobono, L., Profita, M., Bonanno, A., Paterno', A., et al. (2003). Airway cells after swimming outdoors or in the sea in nonasthmatic athletes. Medicine and Science in Sports and Exercise, 35, 1146-1152.

Broeckaert, F., Arsalane, K., Hermans, C., Bergamaschi, E., Brustolin, A., \& Mutti, A. (2000). Serum Clara cell protein: A sensitive biomarker of increased lung epithelium permeability caused by ambient ozone. Environmental Health Perspectives, 108, 533-537.

Brunekreef, B., Hoek, G., Breugelmans, O., \& Leentvaar, M. (1994). Respiratory effects of low-level photochemical air pollution in amateur cyclists. American fournal of Respiratory and Critical Care Medicine, 150, 962-966.

Carlisle, A. J., \& Sharp, N. C. C. (2001). Exercise and outdoor ambient air pollution. British fournal of Sports Medicine, 35, 214-222.

Chimenti, L., Morici, G., Paterno, A., Bonanno, A., Siena, L., Licciardi, A., et al. (2007). Endurance training damages small airway epithelium in mice. American fournal of Respiratory and Critical Care Medicine, 175, 442-449.

D’Amato, G., Liccardi, G., D’Amato, M., \& Cazzola, M. (2002). Outdoor air pollution, climatic changes and allergic bronchial asthma. European Respiratory fournal, 20, 763-776.

Davis, M. S., Lockard, A. J., Marlin, D. J., \& Freed, A. N. (2002). Airway cooling and mucosal injury during cold weather exercise. Equine Veterinary fournal Supplement, 34, 413-416.

Davis, M. S., Schoefield, B., \& Freed, A. N. (2003). Repeated peripheral airway hyperpnea causes inflammation and remodelling in dogs. Medicine and Science in Sports and Exercise, 35, 608-616.

Denguezli, M., Ben Chiekh, I., Ben Saad, H., Zaouali-Ajina, M., Tabka, Z., \& Zbidi, A. (2008). One-year endurance training: Effects on lung function and airway inflammation. Fournal of Sports Sciences, 26, 1351-1359.

Ebi, K. L., \& McGregor, G. (2008). Climate change, tropospheric ozone and particulate matter, and health impacts. Environmental Health Perspective, 116, 1449-1455.

Fievez, L., Kirschvink, N., Dogne, S., Jaspar, F., Merville, M. P., Bours, V., et al. (2001). Impaired accumulation of granulocytes in the lung during ozone adaptation. Free Radical Biology and Medicine, 31, 633-641.
Garcia-Aymerich, J., Lange, P., Benet, M., Schnohr, P., \& Anto, J. M. (2007). Regular physical activity modifies smoking-related lung function decline and reduces risk of chronic obstructive pulmonary disease: A population-based cohort study. American Fournal of Respiratory and Critical Care Medicine, 175, 458-463.

Hashimoto, S., Matsumoto, K., Gon, Y., Nakayama, T., Takeshita, I., \& Horie, T. (1999). Hyperosmolarity-induced interleukin-8 expression in human bronchial epithelial cells through p38 mitogen-activated protein kinase. American fournal of Respiratory and Critical Care Medicine, 159, 634-640.

Haslett, C. (1999). Granulocytes apoptosis and its role in the resolution and control of lung inflammation. American fournal of Respiratory and Critical Care Medicine, 160, S5-S11.

Hermans, C., Knoops, B., Vieding, M., Arsalane, K., Toubeau, G., Famagne, P., et al. (1999). Clara cell protein as marker of Clara cell damage and bronchoalveolar blood barrier permeability. European Respiratory fournal, 13, 1014-1021.

Holz, O., Jorres, R. A., Timm, P., Mucke, M., Koschyk, S., \& Magnussen, H. (1999). Ozone-induced airway inflammatory changes differ between individuals and are reproducible. American fournal of Respiratory and Critical Care Medicine, 159, 776-784.

Huang, Y. C., Li, Z., Harder, S. D., \& Soukup, J. M. (2004). Apoptotic and inflammatory effects induced by different particles in human alveolar macrophages. Inhalation Toxicology, 16, 863-878.

Ishii, Y., Hashimoto, K., Nomura, A., Sakamoto, T., Uchida, Y., Ohtsuka, M., et al. (1998). Elimination of neutrophils by apoptosis during the resolution of acute pulmonary inflammation in rats. Lung, 176, 89-98.

Jabbour, A. J., Altman, L. C., Wight, T. N., \& Luchtel, D. L. (1998). Ozone alters the distribution of beta 1 integrins in cultured primate bronchial epithelial cells. American fournal of Respiratory Cell and Molecular Biology, 19, 357-365.

Karjalainen, E. M., Laitinen, A., Sue-Chu, M., Altraja, A., Bjermer, L., \& Laitinen, L. A. (2000). Evidence of airway inflammation and remodeling in ski athletes with and without bronchial hyperresponsiveness to methacholine. American fournal of Respiratory and Critical Care Medicine, 161, 2086-2091.

Kobayashi, Y. (2008). The role of chemokines in neutrophil biology. Frontiers in Bioscience, 13, 2400-2407.

Koller, D. Y., Nething, I., Otto, J., Urbanek, R., \& Eichler, I. (1997). Cytokine concentrations in sputum from patients with cystic fibrosis and their relation to eosinophil activity. American Fournal of Respiratory and Critical Care Medicine, 155, 1050-1054.

Lebowitz, M. D. (1996). Epidemiological studies of the respiratory effects of air pollution. European Respiratory fournal, 9, 10291054.

Miller, M. R., Hankinson, J., Brusasco, V., Burgos, F., Casaburi, R., Coates, A., et al. (2005). ATS/ERS Standardization of Lung Function Testing: Standardization of spirometry. European Respiratory fournal, 26, 319-338.

Morici, G., Bonsignore, M. R., Zangla, D., Riccobono, L., Profita, M., Bonanno, A., et al. (2004). Airway cell composition at rest and after an all-out test in competitive rowers. Medicine and Science in Sports and Exercise, 36, 1723-1729.

Nanson, C. J., Burgess, J. L., Robin, M., \& Bernard, A. (2001). Exercise alters serum pneumoprotein concentrations. Respiration Physiology, 127, 259-265.

Nieman, D. C. (1994) Exercise, upper respiratory tract infection, and the immune system (review). Medicine and Science in Sports and Exercise, 26, 128-139.

Popov, T., Pizzichini, M. M. M., Pizzichini, E., Kolendowich, R., Punthakee, Z., Dolovich, J., et al. (1995). Some technical factors influencing the induction of sputum for cell analysis. European Respiratory fournal, 8, 559-565. 
Quanjer, P. H. (1986). Standardized lung function testing: Report of the working party. Bullettin Europeen de Physiopathologie Respiratoire, 19, 1-95.

Rusznak, C., Devalia, J. L., \& Davies, R. J. (1996). The airway response of asthmatics to inhaled allergens after exposure to pollutants. Thorax, 344, 1668-1671.

Rytila, P., Plataki, M., Bucchieri, F., Uddin, M., Nong, G., Kinnula, V. L., et al. (2006). Airway neutrophilia in COPD is not associated with increased neutrophil survival. European Respiratory Fournal, 28, 1163-1169.

Spence, L., Brown, W. J., Pyne, D. B., Nissen, M. D., Sloots, T. P., McCormack, J. G., et al. (2007). Incidence, etiology, and symptomatology of upper respiratory illness in elite athletes. Medicine and Science in Sports and Exercise, 39, 577-586.

Sue-Chu, M., Karjalainen, E. M., Laitinen, A., Larsson, L., Laitinen, L. A., \& Bjermer, L. (2000). Placebo-controlled study of inhaled budesonide on indices of airway inflammation in bronchoalveolar fluid and bronchial biopsies in cross-country skiers. Respiration, 67, 417-425.

Sue-Chu, M., Larsson, L., Moen, T., Rennard, S. I., \& Bjermer, L. (1999). Bronchoscopy and bronchoalveolar lavage findings in cross-country skiers with and without "ski asthma". European Respiratory fournal, 13, 626-632.
Tesfaigzi, Y. (2006). Roles of apoptosis in airway epithelia. American fournal of Respiratory Cell and Molecular Biology, 34, 537-547.

Van Wijnen, J. H., Verhoeff, A. P., Jans, H. W. A., \& Van Bruggen, M. (1995). The exposure of cyclists, car drivers and pedestrians to traffic-related air pollutants. International Archives of Occupational and Environmental Health, 67, 187-193.

Viegi, G., \& Enarson, D. A. (1998). Human health effects of air pollution from mobile sources in Europe. International fournal of Tuberculosis and Lung Dissease, 2, 947-967.

Watt, M., Godden, D., Cherrie, J., \& Seaton, A. (1995). Individual exposure to particulate air pollution and its relevance to thresholds for health effects: A study of traffic wardens. Occupational and Environmental Medicine, 52, 790-792.

World Health Organization (2005). Air quality guidelines: Global update 2005. Retrieved from www.euro.who.int/Document/ E90038.pdf 